\title{
Distribution of hepatitis B infection in Brazil: the epidemiological situation at the beginning of the $21^{\text {st }}$ century
}

\author{
Francisco José Dutra Souto[1] \\ [1]. Hospital Universitário Júlio Muller, Universidade Federal de Mato Grosso, Cuiabá, Mato Grosso, Brazil.
}

\begin{abstract}
Brazil was formerly considered a country with intermediate hepatitis B endemicity, with large heterogeneity between Brazilian regions and areas of high prevalence, especially in the Amazon basin. Systematic vaccination of children was initiated in 1998. Between 2004 and 2009, a large population-based study reported decreased prevalence in all regions of Brazil. This review analyzed the current hepatitis B epidemiological situation in Brazil through a systematic search of the scientific literature in MEDLINE, LILACS, and CAPES thesis database, as well as disease notifications to the Information System for Notifiable Diseases. The search strategy identified 87 articles and 13 theses, resulting in 100 total publications. The most recent results indicate reduced hepatitis B prevalence nationwide, classifying Brazil as having low endemicity. Most studies showed HBV carrier prevalence less than $1 \%$. However, there are still isolated regions with increased prevalence, particularly the Amazon, as well as specific groups, such as homeless people in large cities and isolated Afro-descendant communities in the center of the country. This review alsao detected successful vaccination coverage reported in a few studies around the country. The prevalence of anti-HBs alone ranged from $50 \%$ to $90 \%$. However, isolated and distant localities still have low coverage rates. This review reinforces the downward trend of hepatitis B prevalence in Brazil and the need to intensify vaccination strategies for young people and adults in specific regions with persisting higher HBV infection prevalence.
\end{abstract}

Keywords: HBV. Brazil. Epidemiology. Prevalence. Incidence. Vaccine.

\section{INTRODUCTION}

Hepatitis B is a viral infectious disease responsible for significant worldwide human morbidity and mortality. This disease burden is due mainly to complications of chronic infections, such as liver cirrhosis and hepatocellular carcinoma ${ }^{(1)(2)}$. The hepatitis B virus (HBV) is transmitted person-to-person through contact with blood, exudates, and other body fluids such as semen and vaginal secretions. Although iatrogenic dissemination was a common route of transmission throughout the second half of the $20^{\text {th }}$ century due to blood product transfusion and sharing or reuse of syringes and needles, natural routes of transmission are mainly responsible for the high disease prevalence, including sexual, vertical (perinatal, from mother to newborn), and horizontal transmission from environmental exposure in the home, prisons, and other confinement institutions.

Corresponding author: Dr. Francisco José Dutra Souto.

e-mail: fsouto@terra.com.br

Received 25 May 2015

Accepted 17 July 2015

\section{PREVALENCE AND GLOBAL DISTRIBUTION OF HEPATITIS B VIRUS}

The World Health Organization (WHO) classifies hepatitis $\mathrm{B}$ endemicity according to the prevalence of the serological marker of viremia, the hepatitis B surface antigen $(\mathrm{HBsAg})^{(3)}$. The WHO currently categorizes endemicity as low, intermediate low, intermediate high, or high (Table 1).

The disease distribution is quite heterogeneous, with higher prevalence in densely populated Asiatic locations and regions lacking economic and hygienic resources. The most affected region with high endemicity is Southeast Asia. Sub-Saharan Africa, Oceania, and the Amazon basin are other hyperendemic areas. This last region is traditionally considered hyperendemic despite being sparsely inhabited. Indeed, high prevalence rates also have been reported in other populations in remote and poorly inhabited locations, such as among the native Inuits of the Arctic Circle ${ }^{(4)}$. Industrialized countries (North America, Australia, Western Europe, and Scandinavia) have lower endemicity rates. As countries become industrialized, there is a progressive reduction of hepatitis B endemicity concomitant with increasing access to better housing conditions, hygiene, and infrastructure, as reported in Taiwan ${ }^{(5)}$.

Vaccination is another crucial factor for disease control, with effective and safe HBV vaccines first developed in the 1970s. Although initially very expensive, genetic engineering increased production and reduced costs, allowing their use in wide-ranging 
TABLE 1 - World Health Organization classification of hepatitis B virus endemicity, $2015^{(3)}$.

\begin{tabular}{lcccc}
\hline & \multicolumn{4}{c}{ Prevalence } \\
\cline { 2 - 5 } & low & $\begin{array}{c}\text { intermediate } \\
\text { low }\end{array}$ & $\begin{array}{c}\text { intermediate } \\
\text { high }\end{array}$ & high \\
\hline HBsAg+ individuals & $<2 \%$ & $2-4 \%$ & $5-7 \%$ & $\geq 8 \%$ \\
\hline
\end{tabular}

HBsAg: hepatitis B surface antigen.

campaigns and public policies. Evidence from across the globe reveals the effectiveness of vaccination to achieve mediumand long-term endemicity reductions ${ }^{(6)(7)(8)(9)(10)}$. Follow-up of children in Taiwan indicated that it was possible to transform hyperendemic levels to low endemicity ${ }^{(5)}$. Even more striking was the significant decrease in the incidence of liver cancer because of the universal vaccination of youngsters.

The WHO suggests that these changes have decreased the number of HBV carriers and estimates that there are currently about 240 million carriers worldwide ${ }^{(3)(11)(12)}$.

\section{HISTORICAL DISTRIBUTION OF HEPATITIS B VIRUS IN BRAZIL}

At the end of the $20^{\text {th }}$ century, Brazil was classified as having moderate hepatitis B endemicity. Detailed analysis showed a highly heterogeneous distribution of the disease in Brazil. It was long known that the prevalence of hepatitis B increased from the Southern to the Northern regions of the country. The Amazon region has the highest endemicity in Brazil, particularly in Acre, south of the Amazon, as well as Rondônia, Pará, and Northwestern Mato Grosso ${ }^{(13)(14)(15)(16)(17)}$. Data available up to 1999 classified the Southeast, Northeast, and Midwest as regions with low to moderate prevalence, with the exception of the North of Mato Grosso and the mountainous region of Espírito Santo. However, even in southern parts of the country with relatively low endemicity, populations with moderate or high endemic state have been identified, especially in the western parts of the States of Paraná and Santa Catarina ${ }^{(18)}$.

\section{INITIATION OF CHILD VACCINATION IN BRAZIL AND THE NATIONAL EPIDEMIOLOGICAL SURVEY IN BRAZILIAN STATE CAPITALS}

In 1998, the National Immunization Program [Programa Nacional de Imunizações (PNI)] of the Ministry of Health in Brazil mandated vaccination of children against hepatitis B in their first years of life. This policy was gradually extended to cover larger parts of the population as the vaccine became more accessible and the country became self-sufficient in its production. Currently, the hepatitis B vaccine is widely available and recommended for citizens up to 49 years of age. Vaccine coverage has been considered satisfactory, despite the persistent challenge of vaccinating difficult-to-access populations. However, more precise information was required to analyze the effectiveness of the vaccination strategy and the current endemic situation.

Thus, in the past decade, the Ministry of Health has sponsored an ambitious project to estimate the prevalence of viral hepatitis in Brazil. The survey, based on a robust multistage random sampling methodology, evaluated almost 20,000 residents from more than 9,000 households in the 27 Brazilian capitals between 2004 and $2009^{(19)}$. The results indicated a lower than expected prevalence of hepatitis B in all regions ${ }^{(20)}$. Exposure to HBV [measured by levels of antibodies against the core antigen (anti-HBc)] varied in participants 10 to 19 years of age, from $0.6 \%$ in the southeast to $1.6 \%$ in the South. Among individuals 20 to 69 years of age, the prevalence ranged from $7.9 \%$ in the Southeast to $14.7 \%$ in the North. The prevalence rates of virus carriers (HBsAg-positive) among those 10 to 19 years of age did not exceed $0.2 \%$ in any region. For those between 20 and 69 years of age, the HBsAg prevalence ranged from $0.4 \%$ in the Southeast and the Federal District to $0.9 \%$ in the Northern region (Table 2). These numbers moved Brazil to a low-prevalence hepatitis B endemicity classification ${ }^{(3)}$.

\section{CURRENT HEPATITIS B EPIDEMIOLOGICAL DATA IN BRAZIL}

This decline was expected, considering the significant socioeconomic improvements for a large portion of the Brazilian population and effective vaccination coverage, especially among children, from the end of the $20^{\text {th }}$ century. However, the findings of the National Survey remain controversial. The main criticism, acknowledged by the authors, was that limiting the sample to large urban centers (state and federal capitals) could have underestimated the true hepatitis B prevalence in localities with worse health and economic conditions ${ }^{(21)}$.

By excluding the more remote and poorer regions, the study did not sample localities with the highest historical prevalence of hepatitis B in Brazil. For example, the Purus and Juruá River basins in Amazonas historically had the highest rates $^{(22)}$. In the State of Espírito Santo, Cachoeiro de Itapemirim municipality was hyperendemic ${ }^{(23)}$, such as some municipalities in Northwestern Mato Grosso near the border with States of Rondônia and Amazonas ${ }^{(17)(24)}$. The same situation was reported in Cascavel and Francisco Beltrão municipalities of the State of Paraná, and in other countryside of the States of Santa Catarina and Minas Gerais ${ }^{(18)(25)}$. These regions are far from the capital, where improvements in living and hygiene conditions are usually implemented more slowly.

By the beginning of the $21^{\text {st }}$ century, Brazil had become a cosmopolitan and urbanized country, with $84 \%$ of the population living outside rural areas [Censo 2010, Instituto Brasileiro de Geografia e Estatistica (IBGE)]. Considering that less than one-fifth of the population lives in rural areas, it remains unclear whether the results of the National Survey reflect the overall hepatitis B prevalence.

In short, although the results of the National Survey of the Ministry of Health are promising, it is important to continue analyzing data from new Brazilian studies to better understand the current epidemiological environment of hepatitis B, a disease with considerable burdens ${ }^{(2)}{ }^{(12)}$. New data will help assess the impact of vaccination strategies used so far and therapeutic guidelines adopted in recent years, suggesting complementary measures for control of this endemic disease. 
TABLE 2 - Prevalence of markers of current infection (HBsAg-positive) and HBV exposure (anti-HBc-positive) in a population-based survey of capitals of Brazil, coordinated by the UPE and supported by the Ministry of Health and the PAHO ${ }^{(20)}$.

\begin{tabular}{|c|c|c|c|c|c|c|}
\hline Region & $\begin{array}{l}\text { Households/ } \\
\text { participants }\end{array}$ & $\begin{array}{l}\text { Age group } \\
\text { (years) }\end{array}$ & $\begin{array}{c}\text { HBsAg+ } \\
(\%)\end{array}$ & $\begin{array}{c}95 \% \text { CI of } \\
\text { HBsAg (\%) }\end{array}$ & $\begin{array}{c}\text { Anti-HBc }+ \\
(\%)\end{array}$ & $\begin{array}{c}95 \% \mathrm{CI} \text { of } \\
\text { anti-HBc }(\%)\end{array}$ \\
\hline North & 1,084 & $10-19$ & 0.0 & - & 0.9 & $0.4-1.5$ \\
\hline \multirow[t]{2}{*}{ Northeast } & 1,695 & $10-19$ & 0.1 & $0.0-0.3$ & 2.1 & $1.4-2.8$ \\
\hline & 3,650 & $20-69$ & 0.5 & $0.20-0.9$ & 11.7 & $10.0-13.3$ \\
\hline Midwest & 3,653 & $20-69$ & 0.8 & $0.3-1.2$ & 12.7 & $10.9-14.5$ \\
\hline \multirow[t]{2}{*}{ Federal District } & 870 & $10-19$ & 0.2 & $0.0-0.5$ & 1.2 & $0.4-2.0$ \\
\hline & 1,966 & $20-69$ & 0.4 & $0.0-0.8$ & 8.4 & $6.6-10.2$ \\
\hline Southeast & 1,842 & $10-19$ & 0.0 & - & 0.6 & $0.3-0.9$ \\
\hline \multirow[t]{2}{*}{ Brazil } & 9,671 & $10-19$ & 0.05 & $0.0-0.1$ & 1.1 & $0.9-1.4$ \\
\hline & 19,634 & $20-69$ & 0.6 & $0.4-0.8$ & 11.6 & $10.7-12.4$ \\
\hline
\end{tabular}

HBsAg: hepatitis B surface antigen; HBV: hepatitis B virus; anti-HBc: antibodies against hepatitis B core antigen; UPE: University of Pernambuco; PAHO: Pan American Health Organization; 95\%CI: 95\% confidence interval.

\section{METHODOLOGY}

In order to validate and extend the findings of the National Survey, a systematic review was performed using data from independent epidemiological studies on disease prevalence and incidence in Brazil, including historical series.

Scientific publications with primary data on the epidemiology, prevalence, or incidence of hepatitis B in Brazil from 1999 to early 2015 were systematically analyzed. This time interval was defined based on the existence of a publication from 1999 that had compiled all available data available to that time ${ }^{(18)}$.

The MEDLINE, LILACS, CAPES/MEC, and SINAN/MS (Sistema Nacional de Agravos de Notificação, Ministério da Saúde) databases were accessed. In MEDLINE, the following descriptors were entered only in the title/abstract field: (brazil OR brazil*) AND (epidem* OR survey OR prevalence OR incidence OR cross-sectional) AND (hepatitis B OR HBV OR HBsAg). In LILACS, the following descriptor terms in Portuguese, Spanish, and English were used: hepatitis OR hepatite [Words in Title] and epidemiologia OR epidemiology OR prevalencia OR prevalence OR incidencia OR incidence OR survey OR inquerito OR encuesta [Words in Title], and brasil OR brazil [Country of affiliation].

The CAPES/MEC database was queried to find unpublished data. The search strategy used as descriptors hepatitis $B$ and epidemiology or prevalence and incidence or survey in the field title or abstract. We had the helpful assistance of the call center staff, available through the electronic address (mec.cube.callsp.inf.br/ auto-atendimento). The SINAM/MS database was used to collect data on hepatitis B incidence (http://dtr2004.saude.gov.br/sinanweb/).

\section{RESULTS}

The MEDLINE search (http://www.ncbi.nlm.nih.gov/ pubmed) performed on April 4, 2015, resulted in 304 citations. After reviewing the titles and abstracts, studies referring to aspects other than the prevalence or incidence of hepatitis B were discarded, as well as those that focused on subpopulations with increased risk for HBV infection, such as patients with human immunodeficiency virus (HIV), patients in renal replacement therapy, poly-transfused patients, patients with chronic liver disease or scleral jaundice, or patients with sexually transmitted diseases. Articles on prevalence in prison inmates, sex workers, or injectable drug users were discarded because these subpopulations were also considered to have increased risk. Non-injectable drug users, however, were retained in this review. Studies that focused on describing the genotypic distribution of HBV among chronic carriers and research on occult infections were also discarded. After this evaluation, 76 articles remained. Two publications had no data on infection prevalence. One focused only on seroprevalence of vaccine coverage ${ }^{(26)}$, while the other was part of the results of the National Epidemiological Survey in Brazilian State Capitals ${ }^{(20)}$. Thus, 74 articles was retrieved.

A LILACS/BIREME (http://lilacs.bvsalud.org) search on the same day identified 144 studies. First, references that dealt with hepatitis other than hepatitis B were removed from consideration. Results from subpopulations were also discarded, following the same criteria used for the MEDLINE search. After removing articles already identified in the MEDLINE search, 13 additional articles were identified. Thus, from these two databases, 87 publications were retrieved. 
The CAPES database query identified 136 masters or doctoral theses. Most dealt with other aspects of HBV infection, ranging from molecular biology to vaccine considerations. Thirty-four reported prevalence in cross-sectional studies. Among these, 12 had already been identified in the MEDLINE and LILACS searches. Of the remaining 22 , two studies were based in other countries, and seven included only risk groups. Finally, 13 dissertations were identified with unique data, resulting in 100 studies.

The results of these studies are presented below, in four groups. Table 3 presents the results of studies from the beginning of the current millennium, among which many references were related to research and surveys carried out in the 1990s. The most recent population studies or those in specific groups (without increased risk) are shown in Table 4. Table 5 and Table 6 contain data specific to pregnant women and blood donors, respectively. The results in pregnant women are presented separately owing to the fact that these studies have become very common in recent years in Brazil and because they represent in particular the risk of vertical transmission. Blood donors were also separated as a group, with notably reduced prevalence due to increasingly insightful recruitment by blood banks to select individuals with minimal risk.

\section{Results from the turn of the century}

The data in Table 3 show prevalence across the country, with the highest rates concentrated in the Amazon region, including Mato Grosso (27) (28) (29) (30) (31) (32) (33) (34) (35) (36) (37) (38) (39) (40) (41) (42) (43) (44). In all, there were 21 reports, nine $(42.8 \%)$ with intermediate to high prevalence $(>2 \%)$. Of these nine, two had prevalence rates above $9 \%$, namely indigenous people in Lábrea, Amazonas, and isolated African descendants in the State of Mato Grosso do Sul ${ }^{(30)(36)}$. The high prevalence was concentrated, as expected, in the northern region. However, two studies identified high endemicity outside the Amazon basin, in the semi-arid region of the State of Bahia and in African descendants from the Cerrado of the State of Mato Grosso do Sul ${ }^{(34)(36)}$. Five studies reported prevalence below $1 \%$, and the other six assessed anti$\mathrm{HBc}$ positivity rather than HBsAg. The prevalence of this marker in these studies ranged from $1.2 \%$ to $58.4 \%{ }^{(27)(29)(44)}$.

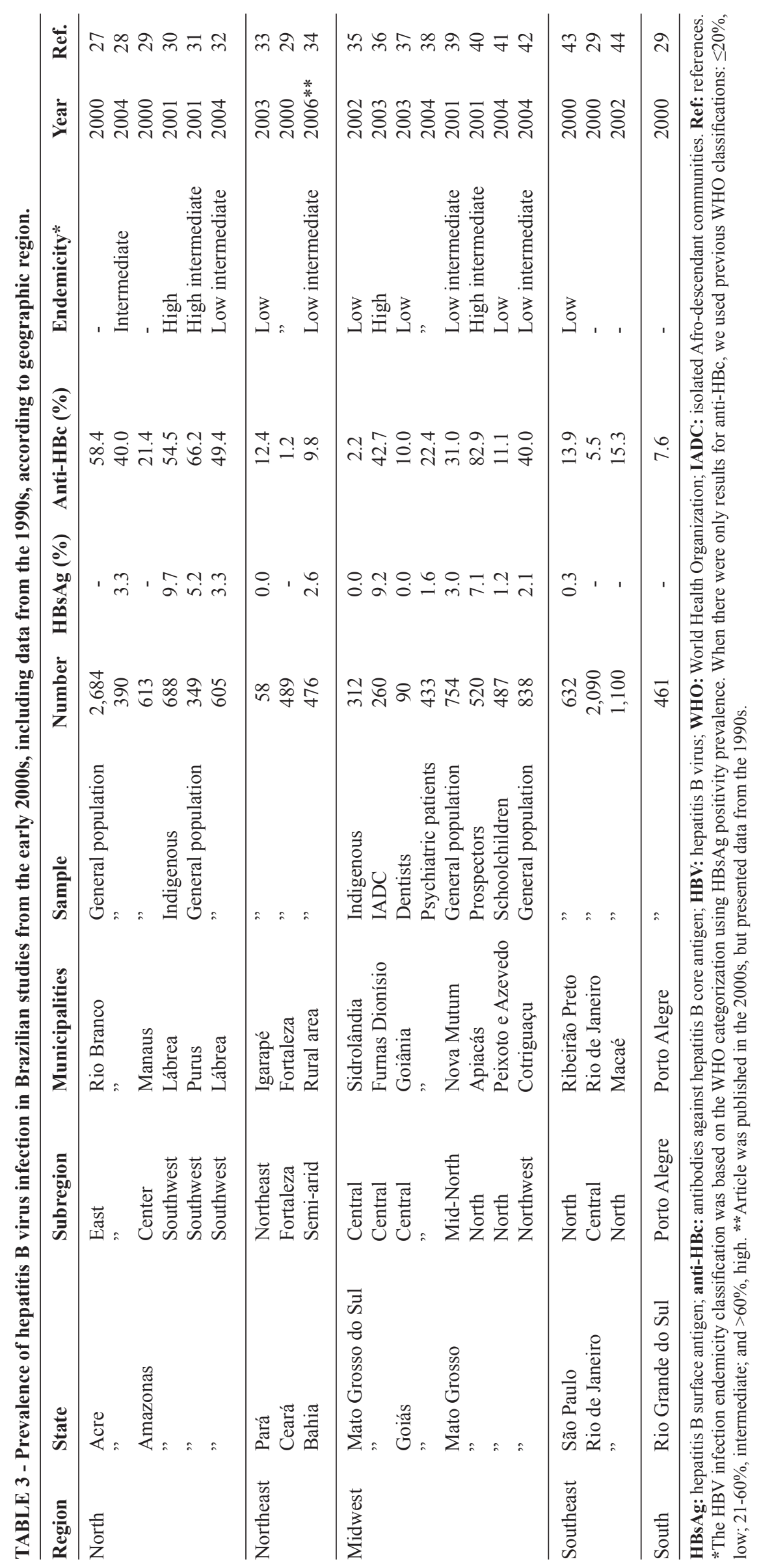




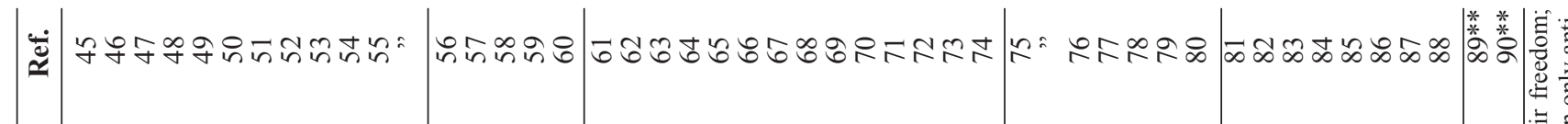

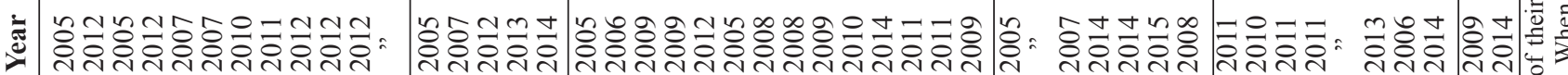

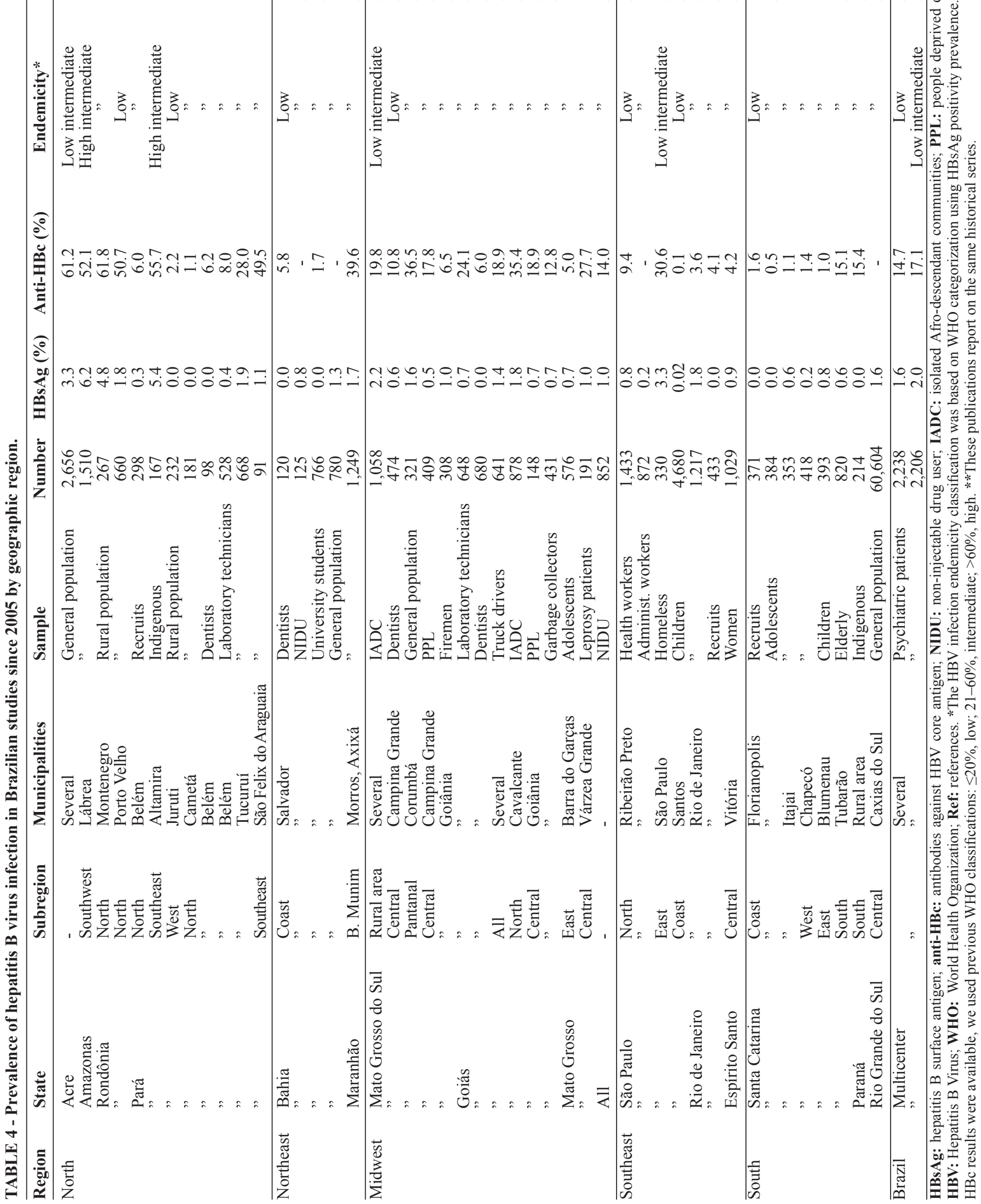


TABLE 5 - Prevalence of hepatitis B virus infection among pregnant women in Brazilian studies since 2000, according to geographic region.

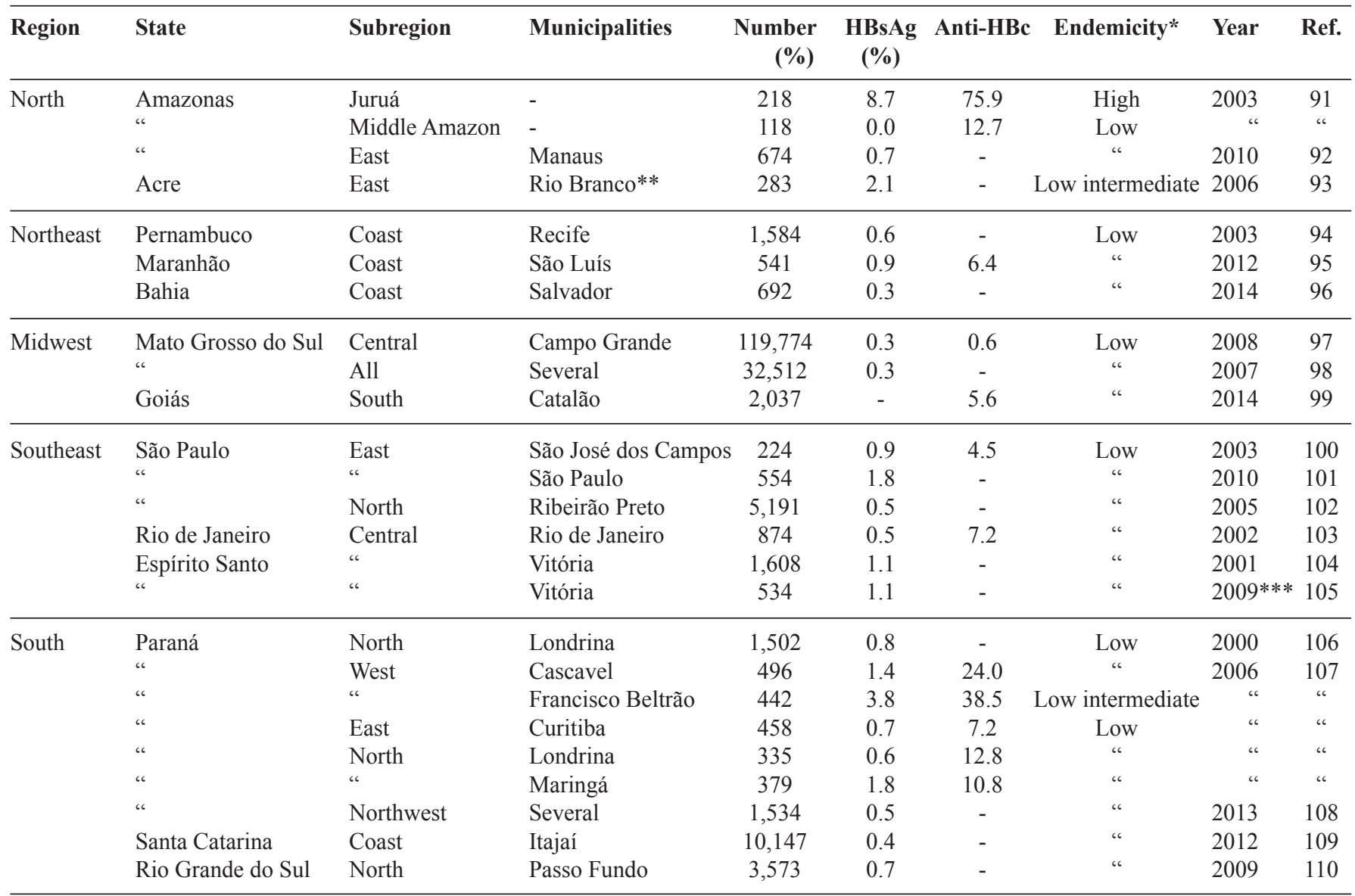

HBsAg: hepatitis B surface antigen; anti-HBc: antibodies against HBV core antigen. *The HBV infection endemicity classification was based on WHO categorization using HBsAg positivity prevalence. When only anti-HBc results were available, we used previous WHO classifications: $\leq 20 \%$, low; $21-60 \%$, intermediate; $>60 \%$, high. Ref: references. **The study by Santos included seven municipalities bordering the Rio Amazonas: Bragança, Castanhal, Combu, Alenquer, Santarém, Óbidos and Oriximiná. ***Article published later in the 2000s but included data from the 1990s.

\section{Recent prevalence data}

Analysis of data from more recent studies (Table 4) suggests lower prevalence rates nationwide ${ }^{(45)(46)(47)(48)(49)(50)(51)(52)(53)(54)}$ (55) (56) (57) (58) (59) (60) (61) (62) (63) (64) (65) (66) (67) (68) (69) (70) (71) (72) (73) (74) (75) (76) (77) (78)(79)(80)(81)(82)(83)(84)(85)(86)(87)(88)(89)(90). These studies represent more than 90,000 individuals. Among 48 reports, only seven $(14.6 \%)$ found intermediate to high prevalence. In $28(58.3 \%)$ studies, the prevalence of HBsAg-positive individuals was below $1 \%$. However, there is no guarantee that individuals were not sampled in more than one such study.

Three Amazonian communities had prevalence higher than $4 \%$, namely Lábrea $(6.2 \%)$, a rural population in Rondônia (4.8\%), and indigenous peoples in Southeastern Pará $(5.4 \%)^{(46)}$ ${ }^{(47)(50)}$. However, in general, the prevalence rates in most recent studies were systematically lower than those in previous studies. Only two studies showed intermediate-low endemicity outside the Amazon Region (3.3\% among homeless in São Paulo, a population considered to be at increased risk, and isolated populations of African descendants in the State of Mato Grosso do $\mathrm{Sul})^{(61)(66)}$. It should also be emphasized that, contrary to studies performed in the 1990 s, the prevalence in more recent studies was less than $7 \%$.

\section{Evaluation of pregnant and postpartum women}

Table 5 presents the results of 25 surveys carried out in pregnant and postpartum women that reported low prevalence, with $16(64 \%)$ of 25 reports showing that HBsAg was present in less than $1.0 \%$ of women ${ }^{(91)(92)(93)(94)(95)(96)(97)(98)(99)(100)(101)(102)}$ (103)(104)(105)(106)(107)(108)(109)(110). Three studies reported intermediate or high endemicity. Two studies were in the Amazon: in Juruá, Amazonas (8.7\% of carriers) in a study from 2003 and in Rio Branco, Acre $(2.1 \%)^{(9)(93)}$. The third study took place in Francisco Beltrão, in Paraná, with $3.8 \%$ endemicity in this population $^{(107)}$.

\section{Blood donor data}

The 15 reports on blood donors totaled over 500,000 donations (Table 6) ${ }^{(75)(111)(112)(113)(114)(115)(116)(117)(118)(119)(120)}$. It was also not possible to rule out double participation between these studies. None of the studies showed prevalence above $0.7 \%$, and 10 reported prevalence below $0.4 \%$. 
TABLE 6 - Prevalence of hepatitis B virus infection among blood donors in Brazilian studies since 2005, according to geographic region.

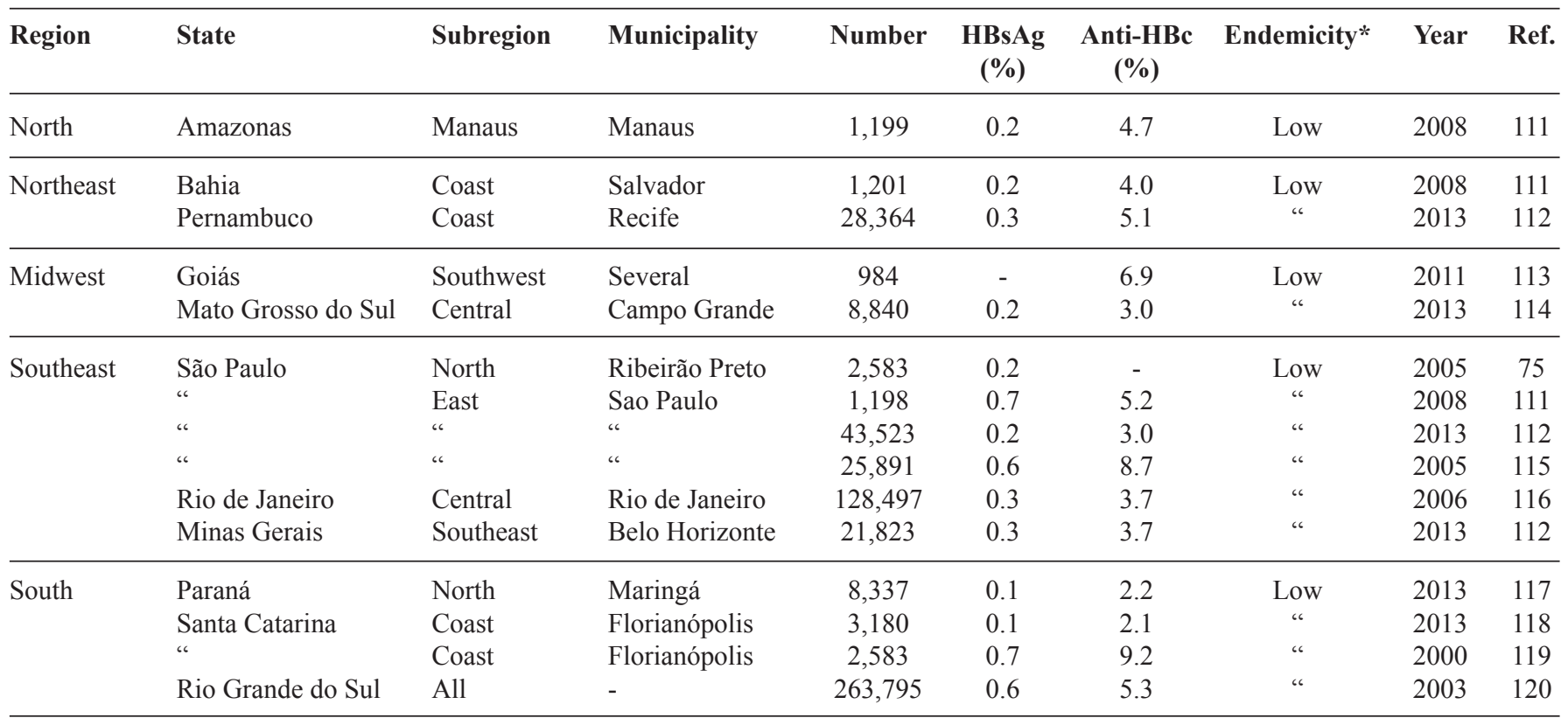

HBsAg: hepatitis B surface antigen; anti-HBc: antibodies against hepatitis B core antigen; WHO: World Health Organization; Ref: references. *The classification of HBV infection prevalence was based on WHO categorization using HBsAg positivity prevalence. When only anti-HBc results were available, we used the previous WHO classification: $\leq 20 \%$, low; $21-60 \%$, intermediate; $>60 \%$, high.

\section{Vaccine coverage}

Among studies included in this review, some also analyzed vaccine coverage by measuring the seroprevalence of antibodies against HBsAg (anti-HBs) ${ }^{(26)(52)(58)(72)(78)(79)(82)(83)(85) . ~ T h e s e ~}$ reports were predominantly conducted in adolescents and young adults. As it is common for people to lose documents certifying vaccination in Brazil, authors often use positivity for anti-HBs positivity alongside negativity for $\mathrm{HBsAg}$ and anti-HBc as evidence of vaccine coverage. Most of these reports found a prevalence of anti-HBs alone between $55 \%$ and $60 \%$, considering the cutoff of $10 \mathrm{UI} / \mathrm{L}$ as the lower level of anti-HB positivity. When anti-HB titers lower than $10 \mathrm{UI} / \mathrm{L}$ were considered, prevalence reaches approximately $90 \%$ (Table 7). However, two studies (Amazon and northeast) suggested low vaccine coverage ${ }^{(52)(60)}$.

\section{Incidence data}

Several studies presented incidence data, including three studies conducted in Santa Catarina. Kupeck (2001) estimated the risk of HBsAg transmission by studying historical blood donor series in the State of Santa Catarina in the $1990 \mathrm{~s}^{(109)}$ and concluded that despite reduced risk, the incidence density would be three infections per 1,000 person-years. More recently, Silva et al. ${ }^{(121)}$ analyzed notifications to the Information System for Notifiable Diseases and estimated that the incidence in 2009 in Brazil and Santa Catarina was 11.5 and 17 infections per 100,000 inhabitants, respectively ${ }^{(121)}$. Finally, Marcon et al. ${ }^{(122)}$ also studied notifications in the same state and concluded that there was a decrease in incidence starting in $2006^{(122)}$.

The Brazilian official data about hepatitis (SVS/MS, 2012) presents data relating to hepatitis $\mathrm{B}$ case notifications from
1999 to $2011^{(123)}$. There is a trend of year-to-year growth. There were fewer notifications among youth $<20$ years of age in Brazil and in all macroregions.

Figure 1 presents reported case data in Brazil from 2007 to 2013 (SINAN) according to age group, with an increasing number of notifications each year. The majority of the cases are concentrated in the 20- to 59-year-old age group. However, below 20 years of age, the number of reported cases is stable. Reports among this age range were $10 \%$ and $5.9 \%$ of the total cases in 2007 and 2013, respectively.

\section{DISCUSSION}

This review shows an improved epidemiological environment in Brazil compared to the end of the last century, likely due to improved quality of life and the increasingly comprehensive deployment of systematic youth vaccination programs. The results presented in Table 3, which correspond to samples obtained at the end of the 1990s, are similar to reports from previous studies, with carrier prevalence exceeding $7 \%$ in some regions, characterizing them as highly endemic ${ }^{(30)(36)(39)}$. In more recent studies, however, this situation has improved, with low to intermediate-high prevalence and no prevalence rates above $7 \%$ (Table 4).

However, there are still foci of intermediate endemicity, especially in areas difficult to access or with low population densities, such as riverine populations in the Amazon Basin and among isolated populations of African descendants (quilombolas) in the Midwest ${ }^{(30)(36)}$.

Two other findings from this review should be emphasized. First, the disease seems to be under control in the Southern region 
TABLE 7 - Prevalence of vaccine-induced protection profile (anti-HBs-positive only) in Brazilian studies.

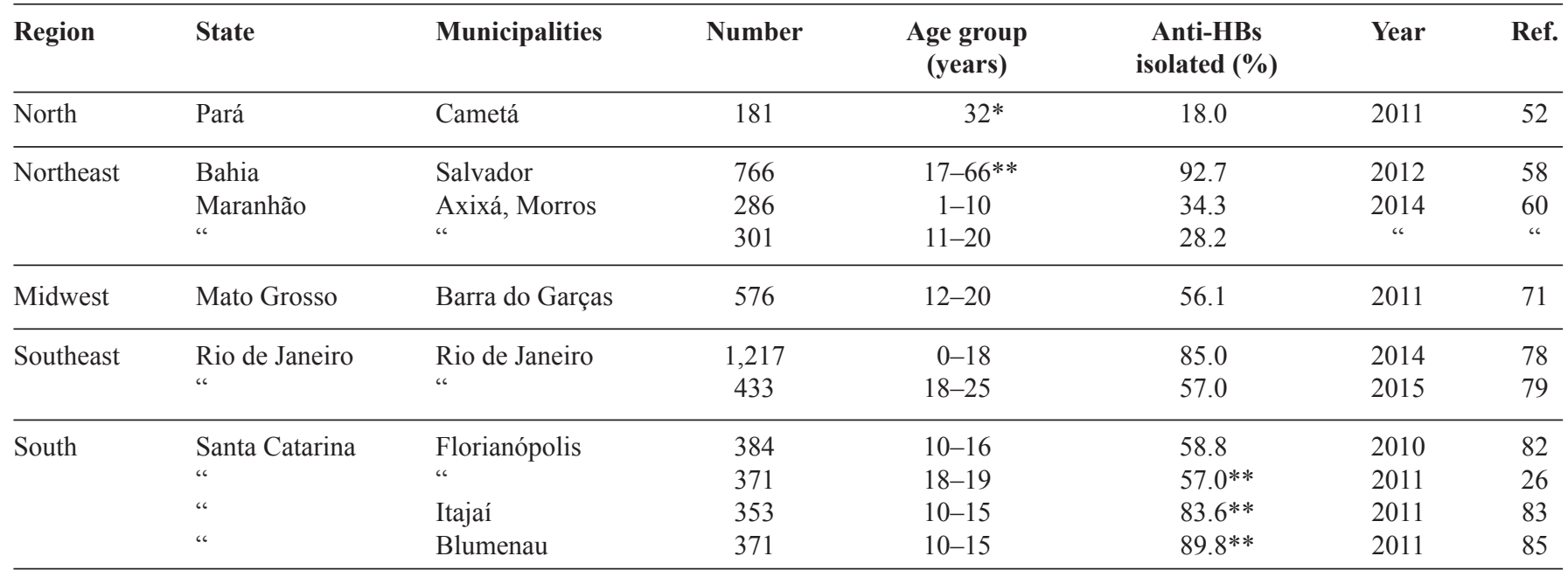

Anti-HBs: antibodies against HBV surface antigen; Ref: references. *Average sample age. The study was conducted in a riverside community in the Amazon interior. **Study of university students between 17 and 66 years of age. $* *$ Considering any anti-HBs titer.

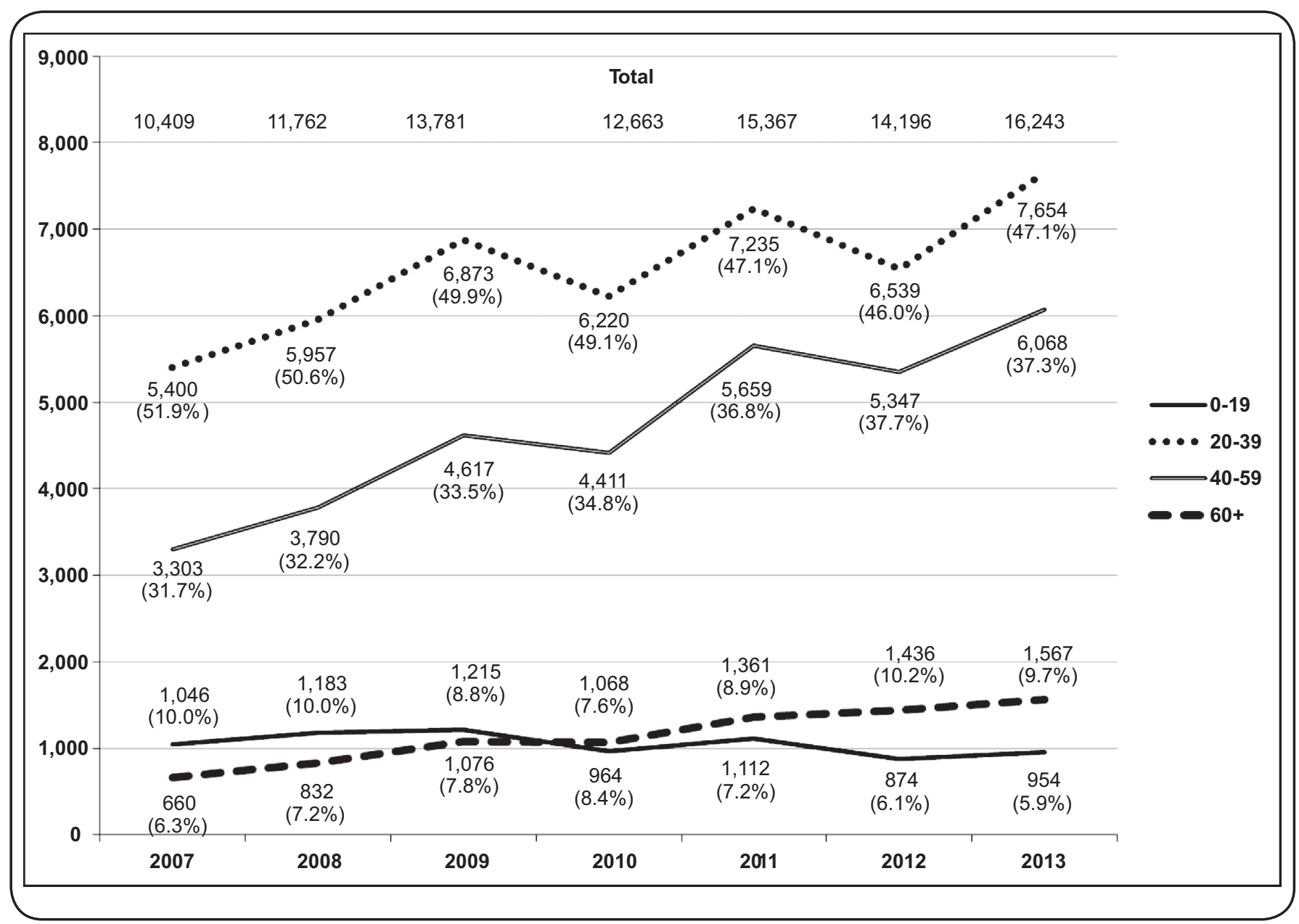

FIGURE 1 - Number (and percentages) of notificated cases of hepatitis B (HBsAg+) in Brazil by age ranges between 2007 and 2013 by age. Source: SINAN/SVS/MS. HBsAg: HBV surface antigen; SINAN/SVS/MS: Sistema Nacional de Notificação de Agravos/Secretaria de Vigilância à Saúde/Ministério da Saúde. 
of the country. A hepatitis B intermediate to high endemicity condition was observed in West States of Paraná and Santa Catarina in the 1990s. Since then, many studies have been conducted, and the states and regional health authorities have worked to identify risk groups and increase vaccine coverage. More recent studies from the Southern regions have reported prevalence rates lower than previously observed, with the exception of pregnant women in Francisco Beltrão ${ }^{(107)}$. These findings suggest successful vaccination coverage in this region $^{(26)(82)(83)(85)}$.

Second, data from northeast Brazil remain relatively scarce, perhaps because hepatitis B has never been a major problem in this region compared to the Northern and Southern states. However, there may be locations in the interior that require a better approach, as observed by Almeida et al. ${ }^{(34)}$ in the semi-arid region of Bahia during the $1990 \mathrm{~s}^{(34)}$.

At-risk groups were not addressed in this review because they are a significant minority of the Brazilian population. However, they are a potential reservoir for dissemination of HBV. Groups such as prisoners, homeless people, drug addicts, people with $\mathrm{HIV}$, and sex workers need specialized approaches to benefit from vaccination and, where appropriate, antiviral therapy.

The data obtained in the SINAN are unreliable as a historical series, as there is no separation between acute and chronic cases, making it impossible to determine when the infection occurred. As a result, the data do not represent incidence rates of new cases. Furthermore, recent infections are added to previous infections that were only recently detected. In addition, the increase in the number of notifications appears to correspond to improvements in the epidemiological surveillance system and notifications for communicable diseases in Brazil. Despite improved socioeconomic conditions and hygiene in a large part of the country, notifications have increased, generating the false impression that the prevalence of many infectious diseases is increasing in Brazil. The same phenomenon has also been observed in hepatitis A. Although analysis of the raw numbers of notifications does not suggest imminent control of hepatitis B in Brazil, the positive trend of decreased or stabilized prevalence among children under 20 years of age indicates the positive effects of vaccination.

Although fewer in number than studies on the prevalence of HBV infection, studies reporting the prevalence of anti-HBs antibodies alone indicate that the levels of coverage offered by vaccination are comparable to those in countries with high vaccine coverage ${ }^{(5)(8)}$. Similar to reports of reduced HBV incidence and prevalence in these countries, Brazil should detect a similar downward trend in the next decade. It is, however, worrying that vaccine coverage was insufficient in remote communities of the Amazon Region and in the Northeast. Efforts must be made to increase vaccination coverage in these localities. In a remote Amazonian community of the State of Mato Grosso, efforts to increase vaccination coverage resulted in reduced prevalence from the high levels previously reported ${ }^{(17)(42)}$.

In short, a systematic literature review of 100 studies on hepatitis B prevalence, incidence, and vaccine coverage suggest that Brazil is progressing toward low endemicity, with specific foci of increased fragility, mainly in the interior of the Amazon region and among remote small communities. The National Survey of the last decade captured the declining trend in major urban regions of the country ${ }^{(20)}$. This review also observed decreasing prevalence in Brazil's innermost part. However, the situation is far from safe. On the contrary, this review underscores the need for increased efforts to control HBV in these specific communities and populations.

\section{CONFLICT OF INTEREST}

The author declare that there is no conflict of interest.

\section{REFERENCES}

1. Ganem D, Prince AM. Hepatitis B virus infection - natural history and clinical consequences. N Engl J Med 2004; 350:1118-1129.

2. Perz JF, Armstrong GL, Farrington LA, Hutin YJ, Bell BP. The contributions of hepatitis $\mathrm{B}$ virus and hepatitis $\mathrm{C}$ virus infections to cirrhosis and primary liver cancer worldwide. J Hepatol 2006; 45:529538.

3. World Health Organization (WHO). Guidelines for the prevention, care and treatment of persons with chronic hepatitis B infection. WHO; 2015. Available at: http://www.who.int/hiv/pub/hepatitis/hepatitis-bguidelines/en/

4. Skinhoj P. Hepatitis and hepatitis B-antigen in Greenland. II: ocurrence and interrelation of hepatitis B associated surface, core and e antigen-antibody system in a highly endemic area. Am J Epidemiol 1977; 105: 99-106.

5. Ni YH, Huang LM, Chang MH, Yen CJ, Lu CY, You SL, et al. Two decades of universal hepatitis B vaccination in Taiwan: impact and implication for future strategies. Gastroenterol 2007; 132:1287-1293.

6. Whittle HC, Maine N, Pilkington J, Mendy M, Fortuin M, Bunn J, et al. Long-term efficacy of continuing 259 hepatitis B vaccination in infancy in two Gambian villages. Lancet 1995; 345:1089-1092.

7. Perz JF, Elm Jr JL, Fiore AE, Huggler JI, Kuhnert WL, Effler PV. Near elimination of hepatitis B virus infections 254 among Hawaii elementary school children after universal infant hepatitis B vaccination. Pediatrics 2006; 118:1403-1408.

8. Zacharakis G, Kotsiou S, Papoutselis M, Vafiadis N, Tzara F, Pouliou $\mathrm{E}$, et al. Changes in the epidemiology of hepatitis B virus infection following the implementation of immunization programmes in northeastern Greece. Euro Surveill 2009; 1-6.

9. Coppola N, Masiello A, Tonziello G, Pisapia R, Pisaturo M, Sagnelli C, et al. Factors affecting the changes in molecular epidemiology of acute hepatitis B in a Southern Italian area. J Viral Hepat 2010; 17:493-500.

10. Lim SG, Mohammed R, Yuen MF, Kao JH. Prevention of hepatocellular carcinoma in hepatitis $\mathrm{B}$ virus infection. J Gastroenterol Hepatol 2009; 24:1352-1357.

11. Ott JJ, Stevens GA, Groeger J, Wiersma ST. Global epidemiology of hepatitis B virus infection: new estimates of age-specific HBsAg seroprevalence and endemicity. Vaccine 2012; 30:2212-2219.

12. Goldstein ST, Zhou F, Hadler SC, Bell BP, Mast EE, Margolis HS. A mathematical model to estimate global hepatitis B disease burden and vaccination impact. Int J Epidemiol 2005; 34:1329-1339.

13. Bensabath G, Boshell J. Presença do antígeno Austrália em populações do interior do Estado do Amazonas, Brasil. Rev Inst Med Trop Sao Paulo 1973; 15:284-288. 
14. Bensabath G, Soares MCP. A hepatite B e delta em Boca do Acre, alto Purus. Moderna Hepatol 1989; 14:36-40.

15. Santos EO, Loureiro ECB, Jesus IM, Brabo E, Silva RSU, Soares MCP, et al. Diagnóstico das condições de saúde de uma comunidade garimpeira na região do Rio Tapajós, Itaituba, Pará, Brasil, 1992. Cad Saude Publica 1995; 11:212-225.

16. Menezes RC, Martins SJ, Soares CP. Prevalência de hepatite B em uma população indígena da Amazônia oriental. In: Anais do XXIX Congresso da Sociedade Brasileira de Medicina Tropical, Fortaleza; 1993. p. 312.

17. Souto FJ, Fontes CJ, Gaspar AM. Outbreak of hepatitis B virus in recent arrivals to the Brazilian Amazon. J Med Virol 1998; 56:4-9.

18. Souto FJ. Distribuição da hepatite B no Brasil: atualização do mapa epidemiológico e proposições para o seu controle. GED Gastroenterol Endosc Dig 1999; 18:143-150.

19. Ximenes RA, Pereira LM, Martelli CM, Hamann EM, Stein AT, Figueiredo GM, et al. Methodology of a nationwide cross-sectional survey of prevalence and epidemiological patterns of hepatitis A, B and C infection in Brazil. Cad Saude Publica 2010; 26:1693-1704.

20. Pereira LM, Martelli CM, Hamann EM, Montarroyos UR, Braga MC, Lima ML, et al. Population-based multicentric survey of hepatitis B infection and risk factor differences among three regions in Brazil. Am J Trop Med Hyg 2009; 81:240-247.

21. Pereira LM, Ximenes RA, Moreira RC, Braga MC, Montarroyos UR. Estudo de prevalência de base populacional das infecções pelos vírus das hepatites A, B e C nas capitais do Brasil. Recife: Universidade de Pernambuco; 2010.

22. Bensabath G, Hadler SC, Soares MP, Fields H, Dias LB, Popper H, et al. Hepatitis delta virus infection and labrea hepatitis: prevalence and role in fulminant hepatitis in the Amazon Basin. JAMA 1987; 258:479483.

23. Ferreira CR, Yoshida CF, Mercadante LA, Gomes DF, Oliveira $\mathrm{JM}$, França MS, et al. Immunization against Hepatitis $B$ in children from endemic zone: evaluation of the antibody response against the DNA recombinant vaccine (Engerix B - $20 \mathrm{mcg}$ ). Rev Inst Med Trop Sao Paulo 1993; 35:89-92.

24. Souto FJ, Fontes CJ, Gaspar AM, Lyra LG. Hepatitis B virus infection in immigrants to the southern Brazilian Amazon. Trans R Soc Trop Med Hyg 1998; 92:282-284.

25. Serufo JC, Silva RA, Lara RG, Rayes AA, Drummond SC, Teixeira $\mathrm{R}$, et al. Alta prevalência de hepatite $\mathrm{B}$ em área endêmica de esquistossomose mansoni. In: Anais do XXXIII Congresso da Sociedade Brasileira de Medicina Tropical. Belo Horizonte; 1997. p. 39.

26. Passos AM, Treitinger A, Spada C. Hepatitis B immunity and vaccination coverage among young adult males in the Air Force in South Brazil. Vaccine 2011; 29:9284-9288.

27. Nascimento LC, Lopes CM. Sexual activity and sexually transmitted diseases in high school students in Rio Branco-Acre, Brazil. Rev Lat Am Enfermagem 2000; 8:107-113.

28. Tavares-Neto J, Almeida D, Soares MC, Uchoa R, Viana S, Darub R, et al. Seroprevalence of hepatitis B and C in the Western Brazilian Amazon region (Rio Branco, Acre): a pilot study carried out during a hepatitis B vaccination program. Braz J Infect Dis 2004; 8:133-139.

29. Clemens SA, Fonseca JC, Azevedo T, Cavalcanti A, Silveira TR, Castilho MC, et al. Hepatitis A and hepatitis B seroprevalence in 4 centers in Brazil. Rev Soc Bras Med Trop 2000; 33:1-10.

30. Braga WS, Brasil LM, Souza RA, Castilho MC, Fonseca JC. The occurrence of hepatitis B and delta virus infection within seven Amerindian ethnic groups in the Brazilian western Amazon. Rev Soc Bras Med Trop 2001; 34:349-355.
31. Paula VS, Arruda ME, Vitral CL, Gaspar AM. Seroprevalence of viral hepatitis in riverine communities from the Western Region of the Brazilian Amazon Basin. Mem Inst Oswaldo Cruz 2001; 96:1123-1128.

32. Braga WS, Brasil LM, Souza RAB, Melo MS, Rosas MDG, Castilho $\mathrm{MC}$, et al. Prevalência da infecção pelos vírus da hepatite B (VHB) e da hepatite Delta (VHD) em Lábrea, Rio Purus, Estado do Amazonas. Epidemiol Serv Saude 2004; 13:35-46.

33. Gadelha MA. Prevalência da infecção pelo vírus da hepatite B em duas comunidades ribeirinhas de afluentes do Tocantins. 2003. 37p. (Master Thesis). Universidade Federal do Pará; 2003 Belém.

34. Almeida D, Tavares-Neto J, Vitvitski L, Almeida A, Mello C, Santana $\mathrm{D}$, et al. Serological markers of hepatitis A, B and C viruses in rural communities of the semiarid Brazilian northeast. Braz J Infect Dis $2006 ; 10: 317-321$.

35. Aguiar JI, Souza JA, Aguiar ES, Oliveira JM, Lemos ER, Yoshida CF. Low prevalence of hepatitis B and C markers in non-amazonian indigenous population. Braz J Infect Dis 2002; 5:269-270.

36. Castro AR, Yoshida CF, Lemos ER, Oliveira JM, Cunha RV, Ximenez LL, et al. Seroprevalence of Hepatitis B virus infection among an Afro-descendant community in Brazil. Mem Inst Oswaldo Cruz 2003; 98:13-17.

37. Carneiro AF, Daher RR. Serum prevalence of hepatitis B virus in anesthesiologists. Rev Bras Anestesiol 2003; 53:672-679.

38. Souza MM, Barbosa MA, Borges AM, Daher RR, Martins RM, Cardoso DD. Seroprevalence of hepatitis B virus infection in patients with mental problems. Rev Bras Psiquiatr 2004; 26:35-38.

39. Souto FJ, Santo GA, Philippi JC, Pietro BR, Azevedo RB, Gaspar AM. Prevalence of and factors associated with hepatitis $B$ virus markers in a rural population of central Brazil. Rev Panam Salud Publica 2001; 10:388-394.

40. Souto FJ, Fontes CJ, Gaspar AM. Prevalence of hepatitis B and C virus markers among malaria-exposed gold miners in Brazilian Amazon. Mem Inst Oswaldo Cruz 2001; 96:751-755.

41. Assis SB, Valente JG, Fontes CJ, Gaspar AM, Souto FJ. Prevalence of hepatitis B viral markers in children 3 to 9 years old in a town in the Brazilian Amazon. Rev Panam Salud Publica 2004; 15: 26-34.

42. Souto FJ, Fontes CJ, Oliveira SS, Yonamine F, Santos DRL, Gaspar AM. Prevalência da hepatite $\mathrm{B}$ em área rural de município hiperendêmico na Amazônia Mato-Grossense: situação epidemiológica. Epidemiol Serv Saude 2004; 13:93-102.

43. Miranda LV, Passos AD, Figueiredo JF, Gaspar AM, Yoshida CF. Serological markers of hepatitis B in people submitted to blood testing in health care clinics. Rev Saude Publica 2000; 34:286-291.

44. Gaze R, Carvalho DM, Werneck GL. Hepatitis A and B seroprevalence in Macaé, Rio de Janeiro State, Brazil. Cad Saude Publica 2002; 18:1251-1259.

45. Viana S, Paraná R, Moreira RC, Compri AP, Macedo V. High prevalence of hepatitis $\mathrm{B}$ virus and hepatitis $\mathrm{D}$ virus in the western Brazilian Amazon. Am J Trop Med Hyg 2005; 73:808-814.

46. Braga WS, Castilho MC, Borges FG, Martinho AC, Rodrigues IS, Azevedo EP, et al. Prevalence of hepatitis B virus infection and carriage after nineteen years of vaccination program in the Western Brazilian Amazon. Rev Soc Bras Med Trop 2012; 45:13-17.

47. Khouri M, Duarte LS, Ribeiro RB, Silva LF, Camargo LM, Santos VA, et al. Seroprevalence of hepatitis B virus and hepatitis C virus in Monte Negro in the Brazilian western Amazon region. Clinics (Sao Paulo) 2005; 60:29-36.

48. Silva ACB. Perfil soro-epidemiológico da hepatite B nas localidades de Cachoeira de Teotônio e Vila Amazonas, Porto Velho - RO, Brasil. 2012. 72 p. (Masters' Dissertation). Universidade Federal de Rondônia; 2012 Porto Velho. 
49. Azevedo LK. Soroprevalência de marcadores para os vírus da hepatite $\mathrm{B}$ (VHB) e vírus da hepatite C (VHC) em militares da ativa que servem em Belém, Pará, Brasil. 2007, 98 p. (Masters Dissertation). Universidade Federal do Pará; 2007 Belém.

50. Nunes HM, Monteiro MR, Soares MC. Prevalence of hepatitis B and D serological markers in the Parakanã, Apyterewa Indian Reservation, Pará State, Brazil. Cad Saude Publica 2007; 23:2756-2766.

51. Nunes HM, Soares MC, Oliveira EM, Costa OS, Alves RS, Maia NC. Prevalência das infecções pelos vírus das hepatites em localidade rural sob influência de um projeto de mineração. Rev Para Med 2010; 24.

52. Oliveira CS, Silva AV, Santos KN, Fecury AA, Almeida MK, Fernandes AP, et al. Hepatitis B and C virus infection among Brazilian Amazon riparians. Rev Soc Bras Med Trop 2011; 44:546-550.

53. Reis ACS. Soroepidemiologia da Infecção pelo Vírus da Hepatite B (VHB) e pelo Vírus da Hepatite C (VHC) cirurgiões-dentistas da cidade de Belém, Pará. 2006. 97 p. (Masters Dissertation). Universidade Federal do Pará; 2006 Belém.

54. Oliveira CM, Nunes MRT, Nunes HM, Soares MC. Prevalência de marcadores sorológicos do vírus da hepatite B em profissionais de saúde de um laboratório de pesquisa na Amazônia oriental, Estado do Pará, Brasil, 2007 a 2009. Epidemiol Serv Saúde 2012; 21:601-616.

55. Almeida MK, Santos KN, Fecury AA, Oliveira CS, Freitas AS, Quaresma JA, et al. Prevalence of viral hepatitis B and C in riverside communities of the Tucuruí Dam, Pará, Brazil. J Med Virol 2012; 84:1907-1912.

56. Braga AS. Prevalência de marcadores sorológicos do vírus da hepatite B em cirurgiões-dentistas de Salvador-BA, após vacinação. 2005. 99 p. (Masters Dissertation). Universidade Federal da Bahia; 2008 Salvador.

57. Nunes CL, Andrade T, Castro BG, Bastos FI, Reingold A. Assessing risk behaviors and prevalence of sexually transmitted and blood-borne infections among female crack cocaine users in Salvador - Bahia, Brazil. Braz J Infect Dis 2007; 11:561-566.

58. Carvalho P, Schinoni MI, Andrade J, Vasconcelos MA, Marques P, Meyer R, et al. Hepatitis B virus prevalence and vaccination response in health care workers and students at the Federal University of Bahia, Brazil. Ann Hepatol 2012; 11:330-337.

59. Matos SB, Jesus AL, Pedroza KC, Sodre HR, Ferreira TL, Lima FW. Prevalence of serological markers and risk factors for bloodborne pathogens in Salvador, Bahia state, Brazil. Epidemiol Infect 2013; 141:181-187.

60. Silva IM. Soroprevalência da infecção pelo vírus da hepatite B e D em dois municípios da região do Baixo Munim, Maranhão, Brasil. 2014. 128 p. (Doctoral thesis). Escola de Enfermagem de Ribeirão Preto; 2014 Ribeirão Preto.

61. Motta-Castro AR, Martins RM, Yoshida CF, Teles SA, Paniago AM, Lima KM, et al. Hepatitis B virus infection in isolated Afro-Brazilian communities. J Med Virol 2005; 77:188-193.

62. Batista SM, Andreasi MS, Borges AM, Lindenberg AS, Silva AL, Fernandes TD, et al. Seropositivity for hepatitis B virus, vaccination coverage, and vaccine response in dentists from Campo Grande, Mato Grosso do Sul, Brazil. Mem Inst Oswaldo Cruz 2006; 101:263-267.

63. Bigaton G. Soroepidemiologia da infecção pelo vírus da hepatite B em população pantaneira. 2009. 92 p. (Master thesis). Universidade Federal de Mato Grosso do Sul; 2009 Campo Grande.

64. Stielf ACF. Estudo soroepidemiológico e molecular da infecção pelo vírus da hepatite B na população prisional de Campo Grande - MS. 2009. (Master thesis). Universidade Federal de Mato Grosso do Sul; 2009 Campo Grande.
65. Moreno LC, Andrade SM, Pontes ER, Stief AC, Pompilio MA, MottaCastro AR. Hepatitis B virus infection in a population exposed to occupational hazards: firefighters of a metropolitan region in central Brazil. Rev Soc Bras Med Trop 2012; 45:463-467.

66. Silva PA, Fiaccadori FS, Borges AM, Silva SA, Daher RR, Martins $\mathrm{RM}$, et al. Seroprevalence of hepatitis B virus infection and seroconvertion to anti-HBsAg in laboratory staff in Goiânia, Goiás. Rev Soc Bras Med Trop 2005; 38:153-156.

67. Paiva EM, Tiplle AF, Silva EP, Cardoso DDP. Serological markers and risk factors related to hepatitis B virus in dentists in the Central West region of Brazil. Braz J Microbiol 2008; 39:251-256.

68. Matos MA, Martins RM, França DDS, Pessoni GC, Ferreira RC, Matos MA, et al. Epidemiology of hepatitis B virus infection in truck drivers in Brazil, South America. Sex Transm Infect 2008; 84:386-389.

69. Matos MA, Reis NR, Kozlowski AG, Teles SA, Motta-Castro AR, Mello FC, et al. Epidemiological study of hepatitis A, B and C in the largest Afro-Brazilian isolated community. Trans R Soc Trop Med Hyg 2009; 103:899-905.

70. Pessoni GC. Rastreamento sorológico e epidemiologia da infecção pelo vírus da hepatite $\mathrm{B}$ em reeducandas do complexo prisional da regional metropolitana de Goiás. 2010. 67 p. (Master thesis). Universidade Federal de Goiás; 2010 Goiânia.

71. Marinho TA, Lopes CL, Teles SA, Matos MA, Matos MA, Kozlowski AG, et al. Epidemiology of hepatitis B virus infection among recyclable waste collectors in central Brazil. Rev Soc Bras Med Trop 2014; 47:1823.

72. Melo LV, Silva MA, Calçada COR, Cavalcante SR, Souto FJ. Hepatitis B virus markers among teenagers in the Araguaia region, Central Brazil: assessment of prevalence and vaccination coverage. Vaccine 2011; 29:5290-5293.

73. Ramos JM, Silva AMC, Martins RM, Souto FJ. Prevalence of hepatitis $\mathrm{B}$ and $\mathrm{C}$ virus infection among leprosy patients in a leprosy-endemic region of central Brazil. Mem Inst Oswaldo Cruz 2011; 106:632-634.

74. Ferreira RC, Rodrigues FP, Teles SA, Lopes CL, Castro ARM, Novais $\mathrm{AC}$, et al. Prevalence of hepatitis B virus and risk factors in Brazilian non-injecting drug users. J Med Virol 2009; 81:602-609.

75. Ciorlia LA, Zanetta DM. Hepatitis B in healthcare workers: prevalence, vaccination and relation to occupational factors. Braz J Infect Dis 2005; 9:384-389.

76. Brito VO, Parra D, Facchini R, Buchalla CM. HIV infection, hepatitis B and C and syphilis in homeless people, in the city of São Paulo, Brazil. Rev Saude Publica 2007; 41 (supl II):47-56.

77. Ciaccia MC, Moreira RC, Lemos MF, Oba IT, Porta G. Epidemiological, serological and molecular aspects of hepatitis B and C in children and teenagers of municipal daycare facilities schools and schools in the city of Santos. Rev Bras Epidemiol 2014; 17:588-599.

78. Villar LM, Amado LA, Almeida AJ, Paula VS, Lewis-Ximenez LL, Lampe E. Low prevalence of hepatitis B and C virus markers among children and adolescents. Biomed Res Int 2014; 2014:324638.

79. Villar LM, Ó KM, Scalioni LP, Cruz HM, Portilho MM, Mendonça $\mathrm{AC}$, et al. Prevalence of hepatitis $\mathrm{B}$ and $\mathrm{C}$ virus infections among military personnel. Braz J Infect Dis 2015; S1413-8670.

80. Miranda AE, Figueiredo NC, Schmidt R, Shafer KP. A populationbased survey of the prevalence of HIV, syphilis, hepatitis B and hepatitis $\mathrm{C}$ infections, and associated risk factors among young women in Vitória, Brazil. AIDS Behav 2008; 12 (supl IV):S25-31.

81. Passos AM. Prevalência dos marcadores sorológicos das hepatites $\mathrm{B}$ e $\mathrm{C}$ e avaliação da imunidade à hepatite $\mathrm{B}$ em adultos jovens da região metropolitana de Florianópolis em 2009. 2011. 138 p. (Masters Dissertation). Universidade Federal de Santa Catarina; 2010 Florianópolis. 
82. Voigt AR, Strazer Neto M, Spada C, Treitinger A. Seroprevalence of hepatitis $\mathrm{B}$ and hepatitis $\mathrm{C}$ markers among children and adolescents in the south Brazilian region: metropolitan area of Florianópolis, Santa Catarina. Braz J Infect Dis 2010; 14:60-65.

83. Tonial GC, Passos AM, Livramento AD, Scaraveli NG, Batschauer AP, Bueno EC, et al. Hepatitis B marker seroprevalence and vaccination coverage in adolescents in the City of Itajaí, State of Santa Catarina, Southern Brazil, in 2008. Rev Soc Bras Med Trop 2011; 44:416-419.

84. Scaraveli NG, Passos AM, Voigt AR, Livramento Ad, Tonial G, Treitinger A, et al. Seroprevalence of hepatitis B and hepatitis C markers in adolescents in Southern Brazil. Cad Saude Publica 2011; 27:753-758.

85. Livramento A, Cordova CM, Spada C, Treitinger A. Seroprevalence of hepatitis $\mathrm{B}$ and $\mathrm{C}$ infection markers among children and adolescents in the southern Brazilian region. Rev Inst Med Trop Sao Paulo 2011; 53:13-17.

86. Machado DF, Martins T, Trevisol DJ, Silva RA, Schiavon JL, Trevisol FS, et al. Prevalence and factors associated with hepatitis B virus infection among senior citizens in a southern Brazilian city. Hepat Mon 2013; 13:e7874.

87. Ferreira A, Greca D, Tavares E, Moriya Y, Spelling F, Boeira M, et al. Seroepidemiology of hepatitis B and C in Kaingang Indians in the south of Brazil. Rev Panam Salud Publica 2006; 20:230-235.

88. Menegol D, Spilki FR. Seroprevalence of Hepatitis B and C markers at the population level in the municipality of Caxias do Sul, southern Brazil. Braz J Microbiol 2014; 44:1237-1240.

89. Guimarães MD, Campos LN, Melo AP, Carmo RA, Machado CJ, Acurcio FA. Prevalence of HIV, syphilis, hepatitis B and C among adults with mental illness: a multicenter study in Brazil. Rev Bras Psiquiatr 2009; 31:43-47.

90. Carmo RA, Melo AP, Dezanet LN, Oliveira HN, Cournos F, Guimarães MD. Correlates of hepatitis B among patients with mental illness in Brazil. Gen Hosp Psychiatry 2014; 36:398-405.

91. Kiesslich D, Fraiji NA, Crispin MA, Pereira FR, Martinho AC, Campello SC, et al. Prevalência de marcadores sorológicos e moleculares do vírus da hepatite $\mathrm{B}$ em gestantes do Estado do Amazonas, Brasil. Epidemiol Serv Saude 2003; 12:155-164.

92. Machado Filho AC, Sardinha JF, Ponte RL, Costa EP, Silva SS, Martinez-Espinosa FE. Prevalência de infecção por HIV, HTLV, VHB e de sífilis e clamídia em gestantes numa unidade de saúde terciária na Amazônia ocidental brasileira. Rev Bras Ginecol Obstet 2010; 32:176183.

93. Santos FCF. Estudo da prevalência do vírus da hepatite B em gestantes de uma maternidade de Rio Branco (Acre). 2006. (Master thesis). Universidade Federal da Bahia; 2006 Salvador.

94. Arraes LC, Sampaio AS; Barreto S, Guilherme MAS, Lorenzato F. Prevalência de hepatite B em parturientes e perfil sorológico perinatal. Rev Bras Ginecol Obstet 2003; 25:571-576.

95. Souza MT, Pinho TL, Santos MD, Santos Ad, Monteiro VL, Fonsêca LM, et al. Prevalence of hepatitis B among pregnant women assisted at the public maternity hospitals of São Luís, Maranhão, Brazil. Braz J Infect Dis 2012; 16:517-520.

96. Boa-Sorte N, Purificação A, Amorim T, Assunção L, Reis A, Castro BG. Dried blood spot testing for the antenatal screening of HTLV, HIV, syphilis, toxoplasmosis and hepatitis B and C: prevalence, accuracy and operational aspects. Braz J Infect Dis 2014; 18:618-624.

97. Botelho MAO. Prevalência da soropositividade dos marcadores da hepatite B (HBsAg e anti-HBc) em gestantes do Programa de Proteção à Gestante de Mato Grosso do Sul, 2004 a 2007. 2008. 86 p. (Master thesis). Universidade de Brasília; 2008 Brasília.

98. Figueiró-Filho EA, Senefonte FR, Lopes AH, Morais OO, Souza Júnior VG, Maia TL, et al. Frequência das infecções pelo HIV-1, rubéola, sífilis, toxoplasmose, citomegalovírus, herpes simples, hepatite B, hepatite C, doença de Chagas e HTLV I/II em gestantes, do Estado de Mato Grosso do Sul. Rev Soc Bras Med Trop 2007; 40:181-187.

99. Fernandes CN, Alves MM, Souza ML, Machado GA, Couto G, Evangelista RA. Prevalence of seropositivity for hepatitis B and C in pregnant women. Rev Esc Enferm USP 2014; 48:91-98.

100. Ribeiro TM. Estudo de soroprevalência e da soroconversão vacinal para a hepatite $\mathrm{B}$ em comunidade atendida em unidade básica de saúde. 2003.78 p. (Doctoral thesis). Universidade de São Paulo; 2003 São Paulo.

101. Gonçalves MA, Matos CC, Spegiorin LC, Oliani DC, Oliani AH, Mattos LC. Seropositivity rates for toxoplasmosis, rubella, syphilis, cytomegalovirus, hepatitis and HIV among pregnant women receiving care at a public health service, São Paulo state, Brazil. Braz J Infect Dis 2010; 14:601-605.

102. Perim EB, Passos ADC. Hepatite B em gestantes atendidas pelo Programa do Pré-Natal da Secretaria Municipal de Saúde de Ribeirão Preto, Brasil: prevalência da infecção e cuidados prestados aos recémnascidos. Rev Bras Epidemiol 2005; 8:272-281.

103. Ximenez LL, Gaspar AM, D'Oro AC, Mercadante LA, Ginuino CF, Yoshida CF. Viral hepatitis markers in antepartum and postpartum women in Rio de Janeiro, Brazil. Mem Inst Oswaldo Cruz 2002; 97:203-204.

104. Miranda AE, Alves MC, Neto RL, Areal KR, Gerbase AC. Seroprevalence of HIV, hepatitis B virus, and syphilis in women at their first visit to public antenatal clinics in Vitória, Brazil. Sex Transm Dis 2001; 28:710-713.

105. Lima LH, Viana MC. Prevalence and risk factors for HIV, syphilis, hepatitis B, hepatitis C, and HTLV-I/II infection in low-income postpartum and pregnant women in Greater Metropolitan Vitória, Espírito Santo State, Brazil. Cad Saude Publica 2009; 25:668-676.

106. Reiche EM, Morimoto HK, Farias GN, Hisatsugu KR, Geller L, Gomes AC, et al. Prevalência de tripanossomíase americana, sífilis, toxoplasmose, rubéola, hepatite $\mathrm{B}$, hepatite $\mathrm{C}$ e da infecção pelo vírus da imunodeficiência humana, avaliada por intermédio de testes sorológicos, em gestantes atendidas no período de 1996 a 1998 no Hospital Universitário Regional Norte do Paraná (Universidade Estadual de Londrina, Paraná, Brasil). Rev Soc Bras Med Trop 2000; 33:519-527.

107. Bertolini DA, Pinho JR, Saraceni CP, Moreira RC, Granato CF, Carrilho FJ. Prevalence of serological markers of hepatitis B virus in pregnant women from Paraná State, Brazil. Braz J Med Biol Res 2006; 39:1083-1090.

108. Ferezin RI, Bertolini DA, Demarchi IG. Prevalência de sorologia positiva para HIV, hepatite $\mathrm{B}$, toxoplasmose e rubéola em gestantes do noroeste paranaense. Rev Bras Ginecol Obstet 2013; 35:66-70.

109. Kupek E, Oliveira JF. Transmissão vertical do HIV, da sífilis e da hepatite B no município de maior incidência de AIDS no Brasil: um estudo populacional no período de 2002 a 2007. Rev Bras Epidemiol 2012; 15:478-487.

110. Liell AP, Weber D, Toscan C, Fornari F, Madalosso LF. Prevalência do HBsAg em gestantes de Passo Fundo, RS: estudo comparativo entre os sistemas de saúde público e privado. Arq Gastroenterol 2009; 46:75-77.

111. Nascimento MC, Mayaud P, Sabino EC, Torres KL, Franceschi S. Prevalence of hepatitis B and C serological markers among first-time blood donors in Brazil: a multi-center serosurvey. J Med Virol 2008; 80:53-57.

112. Almeida-Neto C, Sabino EC, Liu J, Blatyta PF, Mendrone-Junior A, Salles NA, et al. Prevalence of serologic markers for hepatitis B and $\mathrm{C}$ viruses in Brazilian blood donors and incidence and residual risk of transfusion transmission of hepatitis C vírus. Transfusion 2013; $53: 827-834$. 
113. Anjos GR, Martins RM, Carneiro MA, Brunini SM, Teles SA. Epidemiology of hepatitis B virus infection in first-time blood donors in the southwestern region of Goiás, central Brazil. Rev Bras Hematol Hemoter 2011; 33:38-42.

114. Ade SL, Castro ARM, Puga MA, Tanaka TSO, Torres MS, Fitts SMF, et al. Decrease in hepatitis B prevalence among blood donors in Central-West Brazil. J Venom Anim Toxins Incl Trop Dis 2013; 19:7.

115. Valente VB, Covas DT, Passos AD. Marcadores sorológicos das hepatites B e C em doadores de sangue do Hemocentro de Ribeirão Preto, SP. Rev Soc Bras Med Trop 2005; 38:488-492.

116. Andrade AF, Silva MO, Silva SG, Motta IJ, Bonvicino CR. Seroprevalence of hepatitis B and C virus markers among blood donors in Rio de Janeiro, Brazil, 1998-2005. Mem Inst Oswaldo Cruz 2006; 101:673-676.

117. Borelli SD, Mazzola JC, Matta AC, Takemoto AY, Bértoli M. Blood discard rate and the prevalence of infectious and contagious diseases in blood donors from provincial towns of the state of Paraná, Brazil. Rev Bras Hematol Hemoter 2013; 35:395-399.

118. Maccarini JL, Nazario CA, Ferreira JS, Ceglio WQ, Serpa RC, Ferreira VL, et al. Positive serology for viral hepatitis and donor self-exclusion in Southern Brazil. Rev Soc Bras Med Trop 2013; 46:403-410.

119. Treitinger A, Spada C, Ferreira LA, Neto MS, Reis M, Verdi JC, et al. Hepatitis B and hepatitis C prevalence among blood donors and HIV1 infected patients in Florianópolis - Brazil. Braz J Infect Dis 2000; 4:192-196.

120. Rosini N, Mousse D, Spada C, Treitinger A. Seroprevalence of HbsAg, Anti-HBc and anti-HCV in Southern Brazil, 1999-2001. Braz J Infect Dis 2003; 7:262-267.

121. Silva ACLG, Tozatti F, Welter AC, Miranda CDC. Incidência e mortalidade por hepatite B, de 2001 a 2009: uma comparação entre o Brasil, Santa Catarina e Florianópolis. Cad Saude Coletiva 2013; 21:34-39.

122. Marcon CE, Schneider IJ, Traebert J. Temporal trends in the detection rates of hepatitis B in the Santa Catarina State, Brazil. Rev Inst Med Trop Sao Paulo 2014; 56:151-155.

123. Ministério da saúde. Boletim epidemiológico de hepatites virais $\mathrm{n}^{\circ} 1$, ano III, 2012. Brasília: Secretaria de Vigilância à Saúde, Ministério da Saúde. Available at: http://www.aids.gov.br/sites/default /files/ anexos/ publicacao/2012/51820/boletim_epidemiol_gico hepatites virais_2012_ve_12026.pdf. 